\title{
STUDI CEMARAN MIKROBA PADA RENDANG SAPI DI RUMAH MAKAN PADANG DI KECAMATAN KUTA, KABUPATEN BADUNG, BALI
}

\author{
Study of Microbial Contamination on Beef Rendang at Padang Restaurant in Kuta \\ Subdistrict, Badung Regency, Bali
}

\author{
Sixtian Brema Sembiring ${ }^{1)}$, I Nengah Kencana Putra ${ }^{2)}$, Ni Made Indri Hapsari Arihantana') \\ ${ }^{1)}$ Mahasiswa Program Studi Ilmu dan Teknologi Pangan, Fakultas Teknologi Pertanian, Unud \\ ${ }^{2)}$ Dosen Program Studi Ilmu dan Teknologi Pangan, Fakultas Teknologi Pertanian, Unud \\ Kampus Bukit Jimbaran, Badung-Bali
}

\begin{abstract}
The purpose of this study was to determine the microbial contamination on beef rendang and hygiene sanitation practices at Padang restaurant in Kuta subdistrict, Badung regency, Bali. This study used survey method with purposive sampling technique. The sampling determination was conducted at several Padang restaurants in Kuta subdistrict, Badung regency, Bali. The data obtained were presented in the form of tables, pictures, and analyzed descriptively. The variable observed were total microbes, Escherichia coli, and Staphylococcous aureus. The results showed that $90 \%$ of beef rendang was suitable with requirements of total microbes for processed meat in Indonesia $\left(S N I<5 \times 10^{5}\right.$ ), $80 \%$ of beef rendang was suitable with requirements of Escherichia coli for processed meat in Indonesia and 100\% of beef rendang was suitable with requirements of Staphylococcous aureus for processed meat in Indonesia. The amount of $90 \%$ of beef rendang was cooked in the morning, $20 \%$ of rendang was served over 24 hours. The hygiene and sanitation practices at Padang restaurant in Kuta subdistrict, Badung regency were good enough.
\end{abstract}

Keywords : beef rendang, microbial contamination, hygiene sanitation, padang restaurant

\section{PENDAHULUAN}

Bali adalah salah satu provinsi di Indonesia yang banyak dikunjungi oleh wisatawan dalam maupun luar negeri karena keindahan pulau Bali. Kecamatan Kuta memiliki luas wilayah $17,52 \mathrm{~km}^{2}$ yang terbagi atas lima kelurahan yaitu Seminyak, Legian, Kuta, Tuban dan Kedonganan. Rumah makan Padang di kecamatan Kuta diminati karena mudah ditemukan di tepi jalan besar, halal, ekonomis, dan memiliki menu spesial seperti rendang sapi. Pada tahun 2011 Cable News Network (CNN) menetapkan rendang sapi sebagai hidangan peringkat pertama dalam daftar World's 50 most Delicious Food's (Anon., 2017a).

Rendang merupakan makanan tradisional yang berasal dari Sumatera Barat, umumnya dibuat dari daging sapi yang dimasak dengan santan kelapa serta campuran rempah-rempah dan bumbu lainnya. Rendang yang disajikan di rumah makan Padang sangat dikhawatirkan terkontaminasi oleh cemaran mikroba selama proses pengolahan, penyajian yang terlalu lama di suhu ruang, dan penyimpanan. Produsen rumah makan Padang biasanya membuat rendang sekitar $7-10 \mathrm{~kg}$, disajikan di lemari kaca secukupnya dan sisanya disimpan sampai berjam-jam atau berhari-hari di lemari pendingin untuk memenuhi kebutuhan konsumen karena kondisi rumah

*Korespondensi Penulis:

Email: sixtianbrema@gmail.com ${ }^{1)}$ 
makan Padang yang buka sampai 24 jam. Semakin lama penyimpanan masakan daging dan pemanasan kembali akan berpengaruh terhadap mutu mikrobiologi daging sapi (Murhadi et al., 1994).

Pada tahun 2011 warga Bojongsari Depok keracunan setelah mengkonsumsi daging rendang yang dibeli dari rumah makan, karena adanya cemaran bakteri patogen yang disebabkan karena proses pengolahan yang tidak bersih (Anon., 2011a). Daging sapi mudah rusak karena merupakan media yang cocok bagi pertumbuhan mikroba, karena tingginya kandungan air dan zat gizi seperti protein (Fardiaz, 1992).

Bakteri patogen yang mengkontaminasi daging sapi adalah Escherichia coli dan Staphylococcus aureus yang dapat menyebabkan penurunan mutu mikrobiologi daging (Supar, 2005). Pengujian total mikroba dilakukan pada bahan pangan untuk mengetahui gambaran jumlah mikroba pada bahan pangan. Bakteri Escherichia coli menunjukkan bahwa pangan tersebut tercemar oleh kotoran manusia atau hewan yang tercemar dari air (Supardi dan Sukanto, 1999). Staphylococcus aureus merupakan bakteri patogen yang berada di lingkungan bahkan pada tubuh manusia serta mudah untuk mencemari makanan. Staphylococcus aureus umunya berasal dari infeksi misalnya luka, bisul dan jerawat yang pecah (Lund et al., 2000). Praktek higiene dan sanitasi pada rumah makan merupakan kebutuhan utama terhadap terwujudnya keamanan pangan.

Berdasarkan uraian diatas, maka diperlukan penelitian yang bertujuan untuk mengetahui cemaran (total mikroba, Escherichia coli, dan Staphylococcus aureus) pada rendang sapi dan praktek sanitasi higiene rumah makan Padang di kecamatan Kuta, kabupaten Badung, Bali.

\section{METODE PENELITIAN}

\section{Tempat dan Waktu}

Penelitian ini dilaksanakan di Laboratorium
Mikrobiologi PT. Bandar Nelayan Benoa Bali dan rumah makan Padang di kecamatan Kuta, kabupaten Badung, Bali. Penelitian ini dilaksanakan dari bulan Juni sampai Juli 2018.

\section{Bahan dan Alat}

Bahan yang digunakan dalam penelitian ini adalah rendang sapi, larutan BFP (Butterfield's Phospate Buffered), $3 \mathrm{M}$ petriflim ${ }^{\mathrm{TM}} \mathrm{EC}$ plate ( Ingredients : polyester flim, guar gum, nutrients, hinge tape, lactose, pancreatic digest of gelatin), petriflim ${ }^{\mathrm{TM}} \mathrm{AC}$ plate ( Ingredients : Silicone coated paper, polypropylene film, guar gum, hinge tape, media nutrients, sodium pyruvate) dan petriflim $^{\mathrm{TM}}$ STX plate aquades (Ingredients : Nutrient media coated on paper with foam relatining dam and film cover sheet), plastik PE (Polyetilen) dan alkohol 96\%.

Alat yang digunakan dalam pengujian ini adalah cold box (Marina cooler), tabung reaksi (Iwaki), pipet volumetric (Iwaki), pipet mikro (Akura), gelas ukur (Pyrex), medical sterilizer (Fortune), enlemeyer $1000 \mathrm{ml}$ (Pyrex), blue tip, pinset, vortex (Gemmy), bunsen, timbangan analitik (Ohaus), vortex, inkubator (Memert), stomacher 400 circulator (Seward), autoklaf (Hirayama), magnetic stirrer (Thermo scientific), spreader, dan laminar flow.

\section{Rancangan Penelitian}

Penelitian dilakukan dengan menggunakan metode survei dengan teknik pengambilan sampel purposive sampling yaitu pemilihan sampel berdasarkan pertimbangan pertimbangan tertentu (Singarimbun dan Effendi, 2008).

Adapun pertimbangan - pertimbangan yang digunakan adalah rendang sapi rumah makan Padang yang dijual ditepi jalan besar, mudah ditemukan, dan selalu sedia 24 jam di Rumah makan Padang. Total rumah makan Padang yang dijadikan tempat pengambilan sampel sebanyak 10 rumah makan Padang. Pengumpulan data berupa wawancara 
kuisioner. Data hasil penelitian disajikan dalam bentuk tabel, gambar, dan dianalisis secara deskriptif.

\section{Variabel yang diamati}

Variabel yang diamati pada penelitian ini adalah cemaran mikroba (total mikroba, Escherichia coli, dan Staphylococcus aureus) dengan metode sebar pada 3M petriflim food safety (Anon., 2017b) yang telah dievaluasi oleh AOAC official method dan disesuaikan dengan metode pengujian cemaran mikroba dalam olahan daging (Anon., 2008a).

\section{Pelaksanaan Penelitian}

Pengambilan sampel dilakukan pada pukul 24.00 wita di rumah makan Padang kecamatan Kuta. Alat yang digunakan berupa wadah plastik dan ice box yang sudah disterilkan dengan alkohol. Sebanyak $\pm 100 \mathrm{~g}$ yang dibeli dari masing-masing rumah makan Padang dimasukkan ke dalam plastik kemudian disimpan di dalam cold box. Setelah itu, disimpan di freezer dan pada pukul 07.00 wita dibawa ke laboratorium mikrobiologi PT Bandar Nelayan untuk dilakukan analisis cemaran mikroba.

\section{Analisis Total Mikroba (Anon., 2017b)}

Sampel rendang sapi ditimbang $25 \mathrm{~g}$ lalu dimasukkan ke dalam plastik steril yang berisi $225 \mathrm{ml} \mathrm{BFP}$, dihomogenkan dengan stomacher selama 2 menit dan terbentuk pengenceran $10^{-}$ ${ }^{1}$. Dipipet $1 \mathrm{ml}$ larutan homogenan dari tabung $10^{-1}$ ke tabung BFP $10^{-2}$ dan $1 \mathrm{ml} \mathrm{BFP} 10^{-2} \mathrm{ke}$ BFP $10^{-3}$. Diinokulasi $1 \mathrm{ml}$ dari masingmasing tabung ke tengah - tengah petriflim yang dilakukan secara duplo. Diratakan permukaan petriflim AC dengan spreader. Diinkubasi petriflim pada suhu $37^{\circ} \mathrm{C}$ selama 48 jam di inkubator. Koloni mikroba ditandai dengan merah muda bergelembung gas.

Selanjutnya dihitung koloni menurut Fardiaz (1992) dengan rumus koloni yang tumbuh dikali 1/faktor pengenceran.

\section{Analisis Coliform dan Escherichia coli (Anon., 2017b)}

Sampel rendang sapi ditimbang 25 g lalu dimasukkan ke dalam plastik steril yang berisi $225 \mathrm{ml} \mathrm{BFP}$, dihomogenkan dengan stomacher selama 2 menit dan terbentuk pengeceran $10^{-1}$. Dipipet $1 \mathrm{ml}$ larutan homogenan dari tabung $10^{-1}$ ke BFP $10^{-2}, 1 \mathrm{ml}$ BFP $10^{-2}$ ke BFP $10^{-3}$. Diinokulasi $1 \mathrm{ml}$ dari masing-masing tabung ke tengah - tengah petriflim EC yang dilakukan secara duplo. Diratakan permukaan petriflim EC dengan spreader. Diinkubasi petriflim EC pada suhu $37^{\circ} \mathrm{C}$ selama 24 jam di inkubator. Diamati perubahan yang terjadi, Coliform ditandai dengan koloni merah muda dan bergas. Setelah itu petriflim yang positif Coliform dinkubasi kembali selama 24 untuk uji lanjut penentuaan E.coli. Koloni yang positif E.coli ditandai dengan warna biru dan bergelembung gas.

\section{Analisis Staphylococcus Aureus (Anon., 2017b)}

Sampel rendang sapi ditimbang 25 g lalu dimasukkan ke dalam plastik steril yang berisi $225 \mathrm{ml}$ BFP, dihomogenkan dengan stomacher selama 2 menit dan terbentuk pengeceran $10^{-1}$. Dipipet $1 \mathrm{ml}$ larutan homogenan dari tabung $10^{-1}$ ke BFP $10^{-2}, 1 \mathrm{ml}$ BFP $10^{-2} \mathrm{ke}$ BFP $10^{-3}$.

Diinokulasi $1 \mathrm{ml}$ dari masing-masing tabung ke tengah - tengah petriflim Stx yang dilakukan secara duplo. Setelah itu diratakan permukaan petriflim Stx dengan menggunakan spreader supaya tidak terbentuk gelembung udara. Diinkubasi petriflim Stx pada suhu $37^{\circ} \mathrm{C}$ selama 24 jam di inkubator. S.aureus memiliki ciri dengan koloni berwarna merah violet.

\section{HASIL DAN PEMBAHASAN}

\section{Total mikroba}

Hasil pengujian total mikroba pada rendang sapi di rumah makan Padang di kecamatan Kuta, Kabupaten Badung dapat dilihat pada 
Tabel 1.

Tabel 1. Total mikroba pada rendang sapi di rumah makan Padang di kecamatan Kuta, kabupaten Badung, Bali

\begin{tabular}{|c|c|c|c|}
\hline Sampel & $\begin{array}{c}\text { Total } \\
\text { Mikroba } \\
\text { koloni/g }\end{array}$ & $\begin{array}{c}\text { SNI } \\
\text { 7388:2009 } \\
\text { olahan } \\
\text { daging } \\
\text { Koloni/g }\end{array}$ & Keterangan \\
\hline $\mathrm{R}_{1}$ & $1,4 \times 10^{3}$ & $1 \times 10^{5}$ & $\mathrm{~ms}$ \\
\hline $\mathrm{R}_{2}$ & $4,0 \times 10^{2}$ & $1 \times 10^{5}$ & $\mathrm{~ms}$ \\
\hline $\mathrm{R}_{3}$ & $4,3 \times 10^{3}$ & $1 \times 10^{5}$ & $\mathrm{~ms}$ \\
\hline $\mathrm{R}_{4}$ & $3,1 \times 10^{2}$ & $1 \times 10^{5}$ & $\mathrm{~ms}$ \\
\hline $\mathrm{R}_{5}$ & $3,5 \times 10^{2}$ & $1 \times 10^{5}$ & $\mathrm{~ms}$ \\
\hline $\mathrm{R}_{6}$ & $1,5 \times 10^{2}$ & $1 \times 10^{5}$ & $\mathrm{~ms}$ \\
\hline $\mathrm{R}_{7}$ & $2,4 \times 10^{6}$ & $1 \times 10^{5}$ & tms \\
\hline $\mathrm{R}_{8}$ & $1,0 \times 10^{4}$ & $1 \times 10^{5}$ & $\mathrm{~ms}$ \\
\hline $\mathrm{R}_{9}$ & $1,0 \times 10^{3}$ & $1 \times 10^{5}$ & $\mathrm{~ms}$ \\
\hline $\mathrm{R}_{10}$ & $4,5 \times 10^{3}$ & $1 \times 10^{5}$ & $\mathrm{~ms}$ \\
\hline & $\begin{array}{l}\mathrm{ms}(\mathrm{m} \\
\mathrm{tms}(\mathrm{ti}\end{array}$ & $\begin{array}{l}\text { dhi syarat) } \\
\text { lemenuhi } \mathrm{s}\end{array}$ & \\
\hline
\end{tabular}

Pada Tabel 1 menunjukkan bahwa total mikroba pada 10 rendang sapi di rumah makan Padang di kecamatan Kuta berkisar antara 1,5 x $10^{2} \mathrm{koloni} / \mathrm{g}$ sampai $2,4 \times 10^{6} \mathrm{koloni} / \mathrm{g}$. Total mikroba tertinggi ditemukan pada $\mathrm{R}_{7}$ yaitu 2,4 x $10^{6} \mathrm{koloni} / \mathrm{g}$ dan total mikroba terendah ditemukan pada sampel $\mathrm{R}_{6}$ yaitu $1,5 \times 10^{2}$ koloni/g.

Hasil pengujian total mikroba pada Tabel 1 menunjukkan bahwa $90 \%$ rendang sapi di rumah makan Padang kecamatan Kuta memiliki total mikroba dibawah $1 \times 10^{5}$ koloni/g (SNI 7388:2009). Hal ini menunjukkan bahwa $90 \%$ rendang sapi tersebut telah memenuhi syarat batasan maksimum total mikroba pada produk olahan daging dengan panas dalam SNI 7388:2009 (Anon., 2009). Rendang yang memenuhi syarat sebanyak 90\% menunjukkan bahwa proses pengolahan, penyimpanan, dan praktek sanitasi yang baik sehingga berpengaruh terhadap keamanan pangan. Rempah-rempah yang digunakan dalam pembuatan rendang seperti bawang merah, bawang putih, lengkuas, dan cabai berperan sebagai antimikroba pada olahan pangan ( Jenie et al., 1992).

Berdasarkan data total mikoba pada Tabel 1 sebanyak $10 \%$ sampel rendang sapi $\mathrm{R}_{7}$ yang memiliki nilai total mikroba $2.4 \times 10^{6}$ koloni $/ \mathrm{g}$ telah melebihi batasan maksimum jumlah total mikroba, sehingga tidak memenuhi syarat dengan kualitas keamanan pangan yang rendah dan tidak layak untuk dikonsumsi. Dari hasil penelitian survei menunjukkan bahwa tingginya jumlah total mikroba pada $\mathrm{R}_{7}$ dapat disebabkan karena lamanya waktu proses pengolahan pada pukul 21.00 wita, disajikan pada pukul 06.00 wita, dan pengambilan sampel pada pukul 24.00 wita. Penyimpanan di suhu ruang tanpa adanya perlakuan khusus akan mempengaruhi peningkatkan pertumbuhan mikroba $\mathrm{R}_{7}$ dimana dari proses pengolahan sampai pengambilan sampel telah mencapai lebih dari 24 jam.

Menurut Soeparno (2005), jumlah mikroba akan meningkat dengan cepat pada fase pertumbuhan seiring dengan bertambahnya waktu. Faktor yang dapat mempengaruhi pertumbuhan mikroba antara lain air, lingkungan, suhu dan praktek sanitasi higiene. Kontaminasi juga dapat terjadi dalam proses pendistribusian karena lokasi pengolahan yang berbeda dari dapur rumah dibawa ke rumah makan Padang dan proses penyajian serta penyimpanan rendang yang lebih dari 24 jam sehingga dapat meningkatkan jumlah total mikroba. Hasil ini sesuai dengan penelitian (Murhadi et al.,1994) yang menjelaskan bahwa penyimpanan 24 jam di suhu ruang dapat meningkatkan jumlah total mikroba rendang hingga mencapai $8.6 \times 10^{6} \mathrm{koloni} / \mathrm{g}$ sehingga semakin lama proses penyimpanan akan berpengaruh terhadap jumlah total mikroba.

\section{Coliform dan Escherichia coli}

Hasil pengujian Coliform dan E.coli pada rendang sapi di rumah makan Padang di kecamatan Kuta, kabupaten Badung, Bali dapat dilihat pada Tabel 2 . 
Tabel 2. Uji Coliform dan E.coli pada rendang sapi di rumah makan Padang di kecamatan Kuta, Kabupaten Badung, Bali

\begin{tabular}{ccccc}
\hline Sampel & $\begin{array}{c}\text { Coliform } \\
\text { Koloni/g }\end{array}$ & Escherichia coli & $\begin{array}{c}\text { SNI 7388:2009 olahan } \\
\text { daging (Negatif/g) }\end{array}$ & Keterangan \\
\hline $\mathrm{R}_{1}$ & $4,0 \times 10^{2}$ & Negatif & Negatif & Ms \\
$\mathrm{R}_{2}$ & 0 & Negatif & Negatif & Ms \\
$\mathrm{R}_{3}$ & $1,3 \times 10^{2}$ & Negatif & Negatif & Ms \\
$\mathrm{R}_{4}$ & 0 & Negatif & Negatif & Ms \\
$\mathrm{R}_{5}$ & $1,0 \times 10^{2}$ & Negatif & Negatif & Ms \\
$\mathrm{R}_{6}$ & 0 & Negatif & Negatif & Ms \\
$\mathrm{R}_{7}$ & $1,4 \times 10^{3}$ & Positif & Negatif & Tms \\
$\mathrm{R}_{8}$ & $1,3 \times 10^{3}$ & Positif & Negatif & Tms \\
$\mathrm{R}_{9}$ & $1,5 \times 10^{2}$ & Negatif & Negatif & Ms \\
$\mathrm{R}_{10}$ & 0 & Negatif & & Negatif \\
\hline Keterangan : & ms (memenuhi syarat) &
\end{tabular}

Berdasarkan hasil penelitian yang telah dilakukan pada rendang sapi di rumah makan Padang di kecamatan Kuta menunjukkan bahwa $60 \%$ rendang sapi terdapat Coliform setelah diinkubasi selama 24 jam yang ditandai dengan titik merah muda dengan gelembung. Penelitian dari Murhadi et al., (1994) menunjukkan bahwa total Coliform setelah 24 jam pada rendang umumnya meningkat selama proses penyimpanan pada suhu $25-30^{\circ} \mathrm{C}$ dengan wadah terbuka setelah 24 jam yaitu 4,0 $\mathrm{x} 10^{2} \mathrm{koloni} / \mathrm{g}$. Rendang sapi yang terdapat Coliform akan dilakukan uji lanjut penegasan dengan menginkubasi selama 24 jam untuk mengetahui bakteri E.coli positif yang ditandai dengan koloni biru dengan gelembung gas pada media petriflim E.coli/Coliform count plate.

Hasil uji penegasan tersebut menunjukkan bahwa dari 10 rendang sapi didapat sebanyak $2(20 \%)$ rendang sapi yang positif E.coli, yaitu sampel $\mathrm{R}_{7}$ dan rendang $\mathrm{R}_{8}$ sehingga tidak memenuhi standar pada olahan daging dengan keterangan E.coli harus negatif dalam SNI 7388:2009 (Anon., 2009). Keberadaan bakteri ini dalam daging menunjukkan bahwa bahan pangan tersebut pernah tercemar oleh kotoran manusia atau hewan, sehingga dalam mikrobiologi pangan E.coli disebut sebagai indikator sanitasi (Supardi dan Sukanto 1999).
Sumber kontaminasi yang memungkinkan terjadinya cemaran berasal dari air yang telah terkontaminasi E.coli yang digunakan untuk mencuci daging, digunakan pekerja untuk mencuci alat-alat, dan mencuci tangan selama bekerja tanpa menggunakan sabun. Dari hasil kuisioner juga diperoleh bahwa karyawan $\mathrm{R}_{7}$ mencuci tangan seperlunya dan tidak menggunakan sabun, dan lemari kaca $\mathrm{R}_{8}$ hanya dibersihkan bila terlihat kotor dengan kisaran waktu tiga kali seminggu menggunakan kain lap yang sedikit basah. Hal ini dapat menyebabkan kontaminasi dari air yang digunakan ke dalam rendang yang disajikan dilemari kaca. Kontaminasi cemaran E.coli pada $\mathrm{R}_{7}$ dan $\mathrm{R}_{8}$ akan berpengaruh terhadap keamanan pangan. Rendang yang tekontaminasi cemaran E.coli melebihi batas maksimum tidak layak untuk dikonsumsi karena mempengaruhi tingkat keamanan pangan.

Berdasarkan hasil survei dengan wawancara menjelaskan bahwa kontaminasi bakteri patogen E.coli pada sampel $\mathrm{R}_{7}$ dan $\mathrm{R}_{8}$ juga disebabkan karena penanganan rendang seperti cara penyajian dan penyimpanan yang terlalu lama sehingga mengakibatkan bakteri patogen E.coli dapat tumbuh. Kontaminasi pada $\mathrm{R}_{7}$ dan $\mathrm{R}_{8}$ juga disebabkan karena lamanya proses penyajian di lemari kaca yang 
lewat 24 jam dengan keadaan tidak tertutup atau terbungkus. Produsen $\mathrm{R}_{7}$ menyatakan bahwa rendang yang selesai diolah yang tidak disajikan di lemari kaca disimpan di dalam lemari pendingin selama persedian di lemari kaca masih cukup. Kisaran waktu penyimpanan rendang yang biasanya dilakukan oleh rumah makan adalah 48 jam. Setiap jenis makanan menggunakan wadah yang tertutup agar tidak terjadi kontaminasi silang dan dapat memperpanjang masa saji makanan sesuai dengan tingkat keawetan makanan (Anon., 2011b). Rendahnya kebersihan pada peralatan pengolahan pangan juga dapat menyebabkan penyebaran E.coli (Pohan, 2009).

Sebanyak $8(80 \%)$ rendang sapi di rumah makan Padang di kecamatan Kuta negatif E.coli yang ditandai dengan tidak adanya koloni berwarna biru dan bergelembung gas. Hal ini dapat disebabkan karena proses pengolahan, penyimpanan, dan sanitasi yang sudah baik. Pengaruh penggunaan rempahrempah seperti cabai dengan kandungan oleoresin dapat menghambat pertumbuhan Escherichia coli (Maharani dan Warsiki, 2014).

\section{Staphylococcus aureus}

Berdasarkan hasil penelitian pada rendang sapi di rumah makan Padang di kecamatan Kuta ditinjau dari S.aureus bahwa sebanyak 10 (100\%) sudah memenuhi syarat pada produk olahan daging dengan nilai 0 koloni $/ \mathrm{g}\left(<1 \times 10^{2}\right.$ koloni/g) (Anon., 2009). Hal ini dibuktikan hasil pengujian S.aureus pada Petriflim Staphylococcus aureus Express tidak menunjukkan tanda koloni berwarna merah violet. Hasil pengujian $S$. aureus pada rendang sapi di rumah makan Padang di kecamatan kuta, Kabupaten Badung, Bali dapat dilihat pada Tabel 3.
Tabel. 3 Uji S. aureus pada rendang sapi di rumah makan Padang di kecamatan Kuta, Kabupaten Badung, Bali

\begin{tabular}{|c|c|c|c|}
\hline Sampel & $\begin{array}{l}\text { S. aureus } \\
\text { (koloni/g) }\end{array}$ & $\begin{array}{c}\text { SNI } \\
7388: 2009 \\
\text { olahan } \\
\text { daging } \\
\text { (koloni/g) }\end{array}$ & Keterangan \\
\hline $\mathrm{R}_{1}$ & 0 & $1 \times 10^{2}$ & $\mathrm{~ms}$ \\
\hline $\mathrm{R}_{2}$ & 0 & $1 \times 10^{2}$ & $\mathrm{~ms}$ \\
\hline $\mathrm{R}_{3}$ & 0 & $1 \times 10^{2}$ & $\mathrm{~ms}$ \\
\hline $\mathrm{R}_{4}$ & 0 & $1 \times 10^{2}$ & $\mathrm{~ms}$ \\
\hline $\mathrm{R}_{5}$ & 0 & $1 \times 10^{2}$ & $\mathrm{~ms}$ \\
\hline $\mathrm{R}_{6}$ & 0 & $1 \times 10^{2}$ & $\mathrm{~ms}$ \\
\hline $\mathrm{R}_{7}$ & 0 & $1 \times 10^{2}$ & $\mathrm{~ms}$ \\
\hline $\mathrm{R}_{8}$ & 0 & $1 \times 10^{2}$ & $\mathrm{~ms}$ \\
\hline $\mathrm{R}_{9}$ & 0 & $1 \times 10^{2}$ & $\mathrm{~ms}$ \\
\hline $\mathrm{R}_{10}$ & 0 & $1 \times 10^{2}$ & $\mathrm{~ms}$ \\
\hline
\end{tabular}

Berdasarkan hasil survei wawancara dan pengamatan langsung yang telah dilakukan, tidak adanya kontaminasi S.aureus pada rendang sapi di rumah makan Padang di kecamatan Kuta karena telah menerapkan praktek higiene yang baik. Praktek personal higiene yang baik seperti menggunakan pakaian kerja yang bersih, memiliki kondisi badan yang sehat, tidak sedang batuk dan pilek, tidak memiliki luka pada kulit, menjaga kuku tangan bersih dan pendek untuk mencegah kontaminasi dari S.aureus. Kontaminasi S.aureus umumnya berasal dari infeksi, misalnya luka dan bisul pada manusia, serta jerawat yang pecah (Lund et al., 2000).

Pencegahan kontaminasi S.aureus pada makanan dapat dilakukan dengan menghindarkan pekerja yang sedang sakit dalam proses pengolahan makanan karena bakteri patogen ini ditemukan pada manusia, seperti pada hidung, kerongkongan, dan luka terbuka. Hasil wawancara dan pengamatan pada rumah makan Padang menunjukkan bahwa 100\% karyawan tidak diizinkan untuk bekerja jika dalam keadaan sakit, karena produsen mengkhawatirkan dapat terjadi kontaminasi bakteri patogen pada 
makanan yang dijual. Beberapa jenis rempahrempah yang diketahui memiliki aktivitas antimikroba yang cukup kuat adalah bawang merah, bawang putih, cabai dan jahe (Jenie et al, 1992).

\section{Praktek Sanitasi dan Higiene pada rumah makan Padang}

\section{Kondisi bahan baku rendang}

Hasil survei terhadap kondisi bahan baku dalam pembuatan rendang sapi dapat dilihat pada Tabel 4.

Tabel 4. Hasil survei terhadap kondisi bahan baku pada rendang sapi di rumah makan Padang di kecamatan Kuta kabupaten Badung, Bali

\begin{tabular}{|c|c|c|}
\hline \multirow{3}{*}{$\begin{array}{l}\text { No } \\
1\end{array}$} & Indikator/Variabel & Persentase \\
\hline & Tempat pembelian & \\
\hline & - Pasar & $100 \%$ \\
\hline \multirow[t]{2}{*}{2} & Jenis sapi & \\
\hline & - Lokal & $100 \%$ \\
\hline \multirow[t]{3}{*}{3} & Bahan baku diolah & \\
\hline & - Ya & $30 \%$ \\
\hline & - Tidak & $70 \%$ \\
\hline 4 & $\begin{array}{l}\text { Penyimpanan bahan baku } \\
\text { - Freezer } \\
\text { - Tidak disimpan }\end{array}$ & $\begin{array}{l}70 \% \\
30 \%\end{array}$ \\
\hline \multirow[t]{3}{*}{5} & $\begin{array}{l}\text { Maksimal } \\
\text { penyimpanan }\end{array}$ & \\
\hline & $-<1$ hari & $70 \%$ \\
\hline & - tidak disimpan & $30 \%$ \\
\hline
\end{tabular}

Berdasarkan hasil data survei penelitian menunjukkan bahwa produsen di rumah makan Padang di kecamatan Kuta sebanyak $100 \%$ mendapatkan bahan baku dari pasar yang berada di Kabupaten Badung seperti pasar badung dan senggol dan jenis sapi yang digunakan adalah sapi lokal. Kontaminasi bakteri patogen pada bahan baku bisa bermula dari pasar karena kondisi pasar yang tidak dijaga kebersihannya (Utari, 2016). Sebanyak $30 \%$ bahan baku yang diperoleh dari pasar langsung diolah oleh produsen untuk dijadikan rendang dan sebanyak $70 \%$ bahan baku yang dibeli di pasar tidak langsung diolah karena produsen menyimpan di frezzer untuk dikelola di pagi hari dengan kisaran waktu penyimpanan 10 jam.

\section{Kondisi proses pengolahan dan penyimpanan}

Hasil survei terhadap kondisi proses pengolahan dan penyimpanan rendang dapat dilihat pada Tabel 5 .

Tabel 5. Hasil survei kondisi terhadap proses pengolahan rendang dan penyimpanan di rumah makan Padang di kecamatan Kuta, kabupaten, Badung, Bali

\begin{tabular}{llc}
\hline No & \multicolumn{1}{c}{ Indikator/Variabel } & Persentase \\
\hline 1 & Waktu pengolahan rendang sapi & \\
& - Pagi & $90 \%$ \\
& - Malam & $10 \%$ \\
2 & Maksimal lama penyajian & \\
& - 24 jam & $80 \%$ \\
& - > 24 jam & $20 \%$ \\
3 & Maksimal lama penyimpanan & \\
& - > 1 hari & $100 \%$ \\
\hline
\end{tabular}

Berdasarkan hasil data survei penelitian bahwa produsen di rumah makan Padang di kecamatan Kuta pada Tabel 5 menunjukkan bahwa sebanyak $90 \%$ mengolah rendang sapi di pagi hari pukul 05.00 sampai 08.00 wita. Namun sebanyak $10 \%$ produsen yang mengolah rendang di malam hari pada pukul 21.00 wita dan disajikan di pagi hari pukul 06.00 wita. Hal ini dapat memicu pertumbuhan mikroba karena lamanya waktu proses pengolahan, lokasi yang berbeda dan kontaminasi selama di dalam perjalanan. Sesuai dengan pengujian pada $\mathrm{R}_{7}$ maka terbukti total mikroba tidak memenuhi persyaratan karena telah melewati batas maksimum cemaran mikroba olahan daging.

Dalam proses penyajian di lemari kaca, sebanyak $80 \%$ rumah makan Padang menyajikan rendang sampai 24 jam namun biasanya rendang sudah habis sebelum 24 jam sesuai dengan penjualan di rumah makan Padang. Sebanyak 20\% rumah makan Padang yang menyajikan rendang lebih dari 24 jam dan akan diproduksi kembali jikalau persediaan sudah menipis. Rendang sapi yang 
disajikan lebih dari 24 jam dalam keadaan tidak tertutup akan meningkatkan pertumbuhan E.coli seperti pada $\mathrm{R}_{7}$ dan $\mathrm{R}_{8}$. Sisa rendang setelah 24 jam akan dipanaskan dan dicampur dengan rendang yang baru. Pengaruh pemanasan kembali hanya efektif menurunkan total mikroba jika dilakukan kurang lebih 12 jam sejak pembuatan rendang (Murhadi et al., 1994).

Sebanyak $100 \%$ produsen menyimpan rendang sapi dengan wadah tertutup di lemari pendingin karena membuat persediaan sampai dengan satu hari kedepannya. Hal ini dilakukan karena rata-rata produsen membuat rendang sapi hingga $7-10 \mathrm{~kg} /$ hari untuk disajikan secukupnya di lemari kaca dan sisanya disimpan di lemari pendingin.

\section{Personal higiene}

Hasil survei terhadap personal higiene karyawan di rumah makan Padang di kecamatan Kuta, dapat dilihat pada Tabel 6.

Tabel 6. Hasil survei personal hygiene karyawan di rumah makan Padang di kecamatan Kuta, Kabupaten Badung, Bali

\begin{tabular}{llc}
\hline No & \multicolumn{1}{c}{ Indikator/Variabel } & Persentase \\
\hline 1 & $\begin{array}{l}\text { Cara pengambilan sampel } \\
\text { Capit }\end{array}$ & $100 \%$ \\
2 & $\begin{array}{l}\text { Kelengkapan karyawan } \\
\text { Tidak ada }\end{array}$ & $100 \%$ \\
3 & $\begin{array}{l}\text { Frekuensi mencuci tangan } \\
\text { Sebelum dan sesudah }\end{array}$ & $90 \%$ \\
& Seperlunya & $10 \%$ \\
4 & Menggunakan aksesoris cincin & \\
& Ya & $80 \%$ \\
& Tidak & $20 \%$ \\
\hline
\end{tabular}

Berdasarkan hasil data survei penelitian terhadap praktek personal higiene di rumah makan Padang di kecamatan Kuta, menunjukkan bahwa karyawan memiliki kondisi badan yang baik, tidak sedang batuk, pilek, tidak memiliki luka pada kulit, menggunakan pakaian kerja yang bersih dah rapi. Kontaminasi S.aureus umumnya berasal dari infeksi, misalnya luka, bisul, dan jerawat
(Lund et al., 2000). Hal ini berhubungan dengan hasil pengujian seluruh rendang sapi yang memenuhi syarat untuk S.aureus. Ratarata jumlah karyawan yang terdapat dalam rumah makan Padang kecamatan Kuta adalah 3-5 orang. Sebanyak $100 \%$ karyawan menyajikan rendang dengan menggunakan capit, dimana penggunaan capit ini lebih baik dari pada menggunakan tangan, sehingga tidak menyebabkan kontaminasi dari tangan ke rendang sapi. Sebanyak 100\% karyawan tidak ada yang menggunakan kelengkapan karyawan seperti hair net, masker selama proses pengolahan dan sebanyak $90 \%$ karyawan telah menerapkan prinsip mencuci tangan dengan sabun dan sesudah beraktivitas selama mengelola rendang di rumah makan Padang, $10 \%$ hanya mencuci tangan jika diperlukan dan tidak menggunakan sabun. Praktek personal higiene yang tidak baik akan berpengaruh terhadap keamanan pangan.

Cemaran E.coli pada $\mathrm{R}_{7}$ juga disebabkan karena karyawan yang mencuci tangan seperlunya dan tidak menggunakan sabun. Air yang tercemar E.coli dapat menyebabkan kontaminasi pada rendang. Hasil analisis mikroba pada rendang juga membuktikan bahwa $\mathrm{R}_{7}$ terkontaminasi E.coli. Kebiasaan mencuci tangan dapat membantu mencegah terjadinya penularan bakteri dari tangan ke makanan (Arisman, 2009). Sebanyak 80\% karyawan tidak menggunakan aksesoris selama proses pengolahan rendang.

\section{Praktek sanitasi pada rumah makan Padang}

Berdasarkan hasil survei dan pengamatan yang telah dilakukan, menunjukkan bahwa sebanyak $8(80 \%)$ rumah makan Padang telah membersihkan lemari kaca setiap pagi hari sekitar pukul 05.00 wita oleh karyawan dengan menggunakan isopropyl alkohol dan sebanyak 20\% lemari kaca hanya dibersihkan jikalau terlihat kotor. Keberadaan E.coli dalam makanan juga dipengaruhi oleh kurangnya praktek sanitasi yang baik (Pratidina et al., 
2017). Berdasarkan analisis pada $R_{8}$ menunjukkan bahwa terdapat kontaminasi E.coli karena rendahnya praktek sanitasi pada tempat penyajian rendang sapi akan menyebabkan kontaminasi mikroba patogen pada produk. Rendahnya praktek sanitasi pada $\mathrm{R}_{8}$ akan berpengaruh terhadap keamanan pangan. Hasil survei terhadap praktek sanitasi di rumah makan Padang dapat dilihat pada Tabel 7.

Tabel 7. Hasil survei praktek sanitasi di rumah makan Padang di kecamatan Kuta,kabupaten Badung, Bali.

\begin{tabular}{llc}
\hline No & Indikator/ Variabel & Persentase \\
\hline 1 & Membersihkan lemari kaca & \\
& Ya & $80 \%$ \\
& Tidak & $20 \%$ \\
2 & Membersihkan peralatan & \\
& pengolahan rendang & $100 \%$ \\
& Ya & \\
3 & Membersihan dan sanitasi & \\
& ruang pengolahan sebelum \\
& dan sesudah aktivitas & \\
& Ya & $100 \%$ \\
\hline
\end{tabular}

Proses membersihkan peralatan dalam proses pengolahan rendang sapi di rumah makan Padang di kecamatan Kuta secara keseluruhan menggunakan air panas dengan suhu $80^{\circ} \mathrm{C}$ yang dilakukan sebelum memulai aktivitas di rumah makan. Peralatan yang telah dibersihkan disimpan dalam keadaan yang kering. Membersihkan lingkungan sekitar rumah makan juga dilakukan di pagi hari antara lain menyapu, mengepel, dan membuang limbah sampah.

\section{SIMPULAN DAN SARAN}

\section{Simpulan}

Berdasarkan penelitian yang telah dilakukan maka dapat disimpulkan beberapa hal sebagai berikut:

1.Sebanyak 90\% rendang sapi pada rumah makan Padang di kecamatan Kuta, kabupaten Badung, Bali sudah memenuhi syarat total mikroba pada produk olahan daging dengan panas sedangkan 10\% rendang sapi tidak memenuhi syarat.

2.Sebanyak $80 \%$ rendang sapi pada rumah makan Padang di kecamatan Kuta, kabupaten Badung, Bali sudah memenuhi syarat Escherichia coli sedangkan 20\% rendang sapi tidak memenuhi syarat.

3.Seluruh rendang sapi di rumah makan Padang di kecamatan Kuta, kabupaten Badung, Bali sudah memenuhi syarat Staphylococcus aureus pada produk olahan daging dengan panas.

4.Sebanyak 100\% rumah makan Padang di kecamatan Kuta, kabupaten Badung, Bali membeli bahan baku dipasar lokal, 30\% bahan baku langsung diolah, $90 \%$ produsen mengolah rendang di pagi hari, 20\% rendang disajikan melebihi 24 jam, 100\% karyawan tidak menggunakan kelengkapan karyawan namun praktek sanitasi dan higiene sudah cukup baik.

\section{Saran}

Saran yang dapat penulis berikan yaitu pengolahan rendang dilakukan di pagi hari, penyajian tidak lebih dari 24 jam dan meningkatkan praktek sanitasi dan higine untuk menghindari kontaminasi mikroba.

\section{DAFTAR PUSTAKA}

Anonimus. 2008. SNI 2897:2008. Metode Pengujian Cemaran Mikroba Dalam Daging, Telur dan Susu, serta hasil olahannya. BSN, Jakarta.

Anonimus. 2009. SNI 7388:2009. Batas Maksimum Cemaran Mikroba Pada Pangan. BSN, Jakarta.

Anonimus. 2011a. Warga Berjatuhan Setelah Mengonsumsi Daging Rendang. Kompas.https://lifestyle.com/read/2011/ 06/11/030518/wargaberjatuhan.setelah. mengonsumsi.dagin g rendang. 
Diaskes 1 April 2017.

Anonimus. 2011b. Peraturan Mentri Kesehatan Republik Indonesia

No.1096/Menkes/PER/VI/2011. Tentang Higiene Sanitasi Jasaboga. Kementian Kesehatan, Jakarta.

Anonimus. 2017a. World's 50 most best foods.CNN.http://edition.cnn.com/travel/ article/worldbestfoodsreaderchoice/inde x.html.diakses tanggal 30 mei 2018

Anonimus. 2017b. Interperatation Guide 3M Petriflim Microbiology. 3M Food Safety. 3M Petrfilim, Australia.

Arisman. 2009. Buku Ajar Ilmu Gizi: Keracunan Makanan. Jakarta.

Fardiaz, S. 1992. Mikrobiologi Pengelolaan Pangan. Departemen Pendidikan dan Kebudayaan Direktorat Jendral Pendidikan Tinggi, Pusat Antar Universitas Pangan dan Gizi. Institut Pertanian Bogor, Bogor.

Fardiaz, S. 2001. Mikrobiologi Pangan. Gramedia Pustaka Utama, Jakarta.

Jenie. B.S.L., K. Undriyani dan R. Dewanti. 2010. Pengaruh Konsentrasi Jahe dan Waktu Kontak terhadap aktivitas beberapa mikroba penyebab kerusakan pangan. Bul Ilmu dan Teknologi Pangan I1 1(2).

Lund, J.A, Shulman dan A.J. Nahmias. 2000. Staphylocooccal infections: clinical aspects In: Cohen JO,eds. Thestaphylococci, Wiley, New York.

Murhadi., S. Fardiaz dan S. Laksmi. 1994. Pengaruh Penyimpanan dan Pemanasan Kembali terhadap mutu Mikrobiologi Kalio dan Rendang Daging Sapi. Bul. Teknologi Industri Pangan. Vol V no 3 .

Pajan, S.A., O. Waworuntu dan M.A. Leman. 2016. Potensi Antibakteri Air Perasan Bawang Putih (Allium sativun L) terhadap pertumbuhan Staphylococcus aureus. Jurnal Ilmiah Farmasi. Vol. 5 No 4.

Pohan S, D 2009. Pemeriksaan Escherichia coli pada usapan peralatan makan yang digunakan oleh pedagang makanan di pasar petisah medan tahun 2009. Dipublikasi. FKM. USU, Medan.

Pratidina, P., Y.H. Darundiati dan H. L. Dangiran. 2017. Hubungan Higiene Dan Sanitasi Dengan Kontaminasi Escherichia coli Pada Jajanan Pedagang Kaki Lima di Sekolah Dasar Kelurahan Pendrikan Lor, Semarang. Jurnal Kesehatan Masyarakat. Vol 5. No. 5.

Soeparno. 2005. Ilmu dan Teknologi Daging. Gadjah Mada University Press. Yogajakarta.

Singarimbun M. dan S. Effendi. 2008.Metode Penelitian Survei. Lembaga Penelitian, Pendidikan dan Penerangan Ekonomi dan Sosial, Jakarta.

Supar. 2005. Keamanan Pangan Produk Peternakan Ditinjau Dari Aspek Prapanen: Permasalahan dan Solusi. Pusat Penelitian dan Pengembangan Peternakan, Bogor.

Supardi dan Sukanto. 1999. Mikrobiologi Dalam Pengolahan Dan Keamanan Produk Pangan. Alumni, Bandung.

Utari, L.K. 2016. Status Mikrobiologi Daging Broiler di Pasar Tradisional Kab Pringsewu, Dipublikasi. Fakultas Teknologi Pertanian. Univeristas Lampung, Lampung. 